
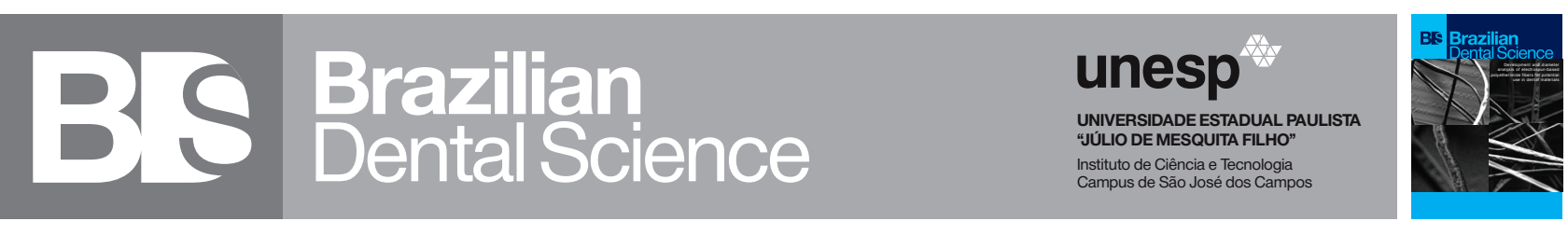

\title{
The Impact of Obesity on Periodontal Health Status in Adolescent Iraqi Students
}

O impacto da obesidade na saúde periodontal de estudantes adolescentes iraquianos

Sarah Ihsan AL-KARAWI ${ }^{1}$, Athraa Ali MAHMOOD ${ }^{1}$, Ban Karem HASSAN ${ }^{1}$

1- Periodontal Department, Dentistry College, Mustansiriyah University, Baghdad-Iraq.

\section{ABSTRACT}

Objetive: The aim of this study was to estimate the effect and association of obesity on the periodontal health status of middle school students. Materials and Methods: This study included 180 secondary school students aged 1215 years from Baghdad City in the survey. BMIfor-age (body mass index for age) was utilized to detect overweight and obesity. Furthermore, periodontal screening records (PSR) index was performed to evaluate the oral hygiene and periodontal condition of the subjects. Chisquare tests and two-way ANOVA were used for statistical analyses. Results: A highly significant association of BMI-for-age with periodontal health (codes $0,1,2$, and 3 ) was observed. The association of gender and periodontal health was highly significant in code 3 , significant in codes 0 and 1 , and it was not significant in code 2 . Additionally, the ANOVA test revealed that the effects of gender and BMI-for-age on periodontal health were significant. In contrast, the effect of the interaction between gender and BMI-for-age on periodontal health was not it was not significant. Conclusions: In adolescents, bad oral hygiene was correlated with extra body fat indicators. Therefore, oral health preventive schedules should take into consideration the relationship between periodontal condition and overweight/obesity in teenagers.

\section{KEYWORDS}

Obesity; Body mass index; Periodontal disease; Oral health status.

\section{RESUMO}

Objetivo: O objetivo deste estudo foi avaliar o efeito e a associação da obesidade no estado de saúde periodontal de estudantes do ensino médio. Materiais e Métodos: Este estudo incluiu 180 alunos do ensino médio com idades entre 12-15 anos da cidade de Bagdá. O IMC (índice de massa corporal) foi utilizado para detectar sobrepeso e obesidade. Além disso, o índice de registro periodontal simplificado (RPS) foi realizado para avaliar a higiene oral e a condição periodontal dos indivíduos. Testes de qui-quadrado e ANOVA de dois fatores foram usados para análises estatísticas. Resultados: Foi observada uma relação altamente significante do IMC com a saúde periodontal (códigos 0, 1, 2 e 3). A relação de gênero e saúde periodontal foi altamente significante no código 3 , significante nos códigos 0 e 1 e não significante no código 2. Além disso, o teste ANOVA revelou que a correlação do sexo e do IMC na saúde periodontal foram significantes. Em contraste, o efeito da interação entre gênero e IMC na saúde periodontal foi não significante. Conclusões: Em adolescentes, a má higiene bucal foi correlacionada com indicadores de gordura corporal extra. Portanto, as programações preventivas de saúde bucal devem levar em consideração a relação entre a condição periodontal e o sobrepeso / obesidade em adolescentes.

\section{PALAVRAS-CHAVE}

Obesidade; Índice de massa corporal; Doença periodontal; Condição de saúde bucal. 


\section{INTRODUCTION}

$\mathrm{T}$ he condition in which body fat is excessively stored and may unfavourably disturb overall health is known as obesity [1]. As the percentages of children and adolescents with high-fat build-up have considerably increased in developing countries, this condition is not limited to only those from advanced nations $[2,3]$.

Obesity, identified by body mass index (BMI), is mutual in various places around the world. It is recognized as a chronic disease, which has multiple aetiologies: hereditary, ecological, socioeconomic, and behavioural influences together appear to be significantly involved [4,5]. Obesity complements mild inflammatory conditions and is estimated to be a predisposing factor for several chronic diseases, such as cardiovascular disease, diabetes, and possibly periodontal disease [6,7].

Similar to the mature populace, obesity in children is universally widespread; additionally, prevalence data demonstrate a growing trend worldwide [4,5]. However, this medical condition in adolescents is still incompletely understood due to the absence of equivalent demonstrative documents from diverse countries, as well as fluctuating measures for describing obesity [4].

Periodontal diseases commonly comprise many infectious and inflammatory conditions caused by the interaction between the host inflammatory response and supra- and subgingival biofilm growth along the tooth surfaces among children, as well as adolescents [8,9]. Periodontal diseases should be considered systemic conditions, meaning that they are both modulated by the body's systems and play a role as a risk factor for systemic disturbance [9]. Smoking, nutritional habits, diabetes mellitus, and psychological stress are risk factors that are commonly encountered, among others, for both periodontal disease and obesity [9].
Epidemiological studies indicate that gingivitis of varying severity is nearly a universal finding in children and adolescents [10]. One study performed in Greece showed a prevalence of gingivitis in adolescents of $73 \%$ in boys and $72 \%$ in girls [11]. The prevalence of periodontitis in adolescents was reported in surveys to be as high as $24 \%$ in the USA [12] and $7 \%$ in Australia [13].

The precise mechanism underlying the progression of periodontal disease has not been confirmed until recently; in addition, diverse reasons, such as amplified production of proinflammatory cytokines, have been theorized to participate in peridontal pathophysiology [14].

In the literature, there have been few comprehensive studies concerning periodontal diseases' association with obesity in young individuals. One of the chief communal health apprehensions is obesity in adolescents, and due to its universal spread and severe outcomes, it can be defined as a pandemic [15].

In 1977, an association between obesity and periodontal diseases was initially stated due to the establishment of periodontium fluctuations in overweight rats [16]. Obesity could be directly connected with periodontitis in humans, as indicated by cross-sectional studies $[17,18]$.

A systematic review by Khan et al., 2018 showed evidence to suggest that obesity is associated with periodontitis in both adolescents and young adults [19]. Another systematic review by Martens et al. in 2017 stated that "The available evidence suggests a significantly positive association between periodontal disease and obesity in children" [20].

The interface of obesity and periodontal conditions was postulated in medical records, for instance, variations in host defence modifications, compromised glucose tolerance, and increased reaction to psychological stress with the production of pro-inflammatory cytokines [21]. 
In preceding years, periodontal disease and obesity have been thoroughly investigated in adults. However, studies exploring this rapport in children and teenagers are limited. Currently, the relationship between oral condition and obesity is not closely established in children and adolescents compared to adults based on the body of systematic knowledge generated from previous studies [22].

Given this gap in knowledge, this study aimed to evaluate and understand the association and effect of overweight/obesity as defined by BMI-for-age on periodontal health as measured by the periodontal screening records (PSR) index among Iraqi school adolescent students of both genders.

\section{MATERIAL AND METHODS}

In 2018 at the Centre of Baghdad, Iraq, this cross-sectional research was conducted and included $(n=180)$ and excluded $(n=60)$ adolescents (12-15) years old from both genders, grade 1-2 of high school education from public schools that were arbitrarily assigned.

Written consent was obtained from the students' parents for agreement and publishing data, and approval for their use was acquired from the local ethical research committee (protocol 1014. 27-Jun-2018).

This study was intended as a comparative observational analysis of oral and periodontal conditions in overweight and obese adolescents compared to average-weight subjects. The investigational group constituted overweight and obese individuals, while the control group was comprised of healthy average weight individuals.

Students with chromosomal diseases or major medical situations or who were taking medications that produce gingival enlargement were excluded. Moreover, data was collected from all subjects, including sex, age, and smoking habits. Participants were restricted to non-smokers because smoking is intensely interconnected with both systemic health and periodontal disease equally [23].

Students were interviewed at their schools, and structured questionnaires were used to collect information. Both clinical and oral examinations were recorded.

Based on BMI-for-age, the groups were designated by values that depended on BMI for each age and gender, describing overweight adolescents and utilizing obesity confines [24].

\section{Auxological Records:}

The auxological information gathered by a sole detective included the following:

- Age

- Weight $(\mathrm{kg})$ of the student dressed

- Height (m) of the student recorded using a measuring tape

Calculation of BMI was indicative of total body adiposity. BMI was calculated as follows: [weight (kg)/height 2 (m2)].

\section{BMI-for-Age}

BMI-for-age [(weight in kilograms)/ (height in metres)2] percentiles, produced and utilized as a growth and nutrition reference by WHO, relied on gender- and particular age weight-for-height charts of individuals from 5-19 years [24]. Consistent with these tables, 'healthy' was recognized as $5 \%<$ BMI-for-age $<85 \%$, 'overweight' as $85 \% \leq$ BMI-for-age < $95 \%$, and obese as BMI-for-age $\geq 95 \%$ [25]. The underweight/undernutrition school students in which BMI-for-age $\leq 5$ th percentile [26] were omitted from investigation of additional records to relate non-fat and obese. When assessing visits, all information was gathered from individuals, and if they fit the inclusion criteria, they were requested to participate in this study. 


\section{Clinical Examinations}

Clinical examinations measured students' periodontal status using the PSR index. Examinations were performed in classes from each school via professionally trained periodontists and under domain circumstances. Subjects sat in a chair with a lengthy backrest, and the inspector was standing anterior to the chair using disposable mirrors, along with WHO periodontal probes. The inspector documented the matching PSR index according to WHO standards. The PSR has five classifications, as shown in Table I [27].

Table I - Periodontal Screening and Recording Index

\begin{tabular}{|c|c|c|c|}
\hline Code & $\begin{array}{l}\text { Bleeding on Probing } \\
\text { (BOP) }\end{array}$ & $\begin{array}{c}\text { Calculus/Defective } \\
\text { Margins }\end{array}$ & $\begin{array}{l}\text { Probing Depth } \\
\text { (PD) }\end{array}$ \\
\hline 4 & \multirow{2}{*}{\multicolumn{2}{|c|}{$\begin{array}{l}\text { Whether } 3 \text { or } 4 \text {, defined as PD. However, it may exceed } \\
\text { if PD represent false pocket without BOP or calculus }\end{array}$}} & More than 5.5 \\
\hline 3 & & & 5.5 \\
\hline 2 & Yes & Yes & \multirow{2}{*}{ Less than 3.5} \\
\hline 1 & Yes & None & \\
\hline 0 & None & None & Less than 3.5 \\
\hline$x$ & \multicolumn{3}{|c|}{ Edentulous Sextant } \\
\hline * & $\begin{array}{l}\text { Add to any code to indicat } \\
\text { Involvement, Mucogir }\end{array}$ & $\begin{array}{l}\text { e any other signs such as M } \\
\text { tgival defects, Recession (3. }\end{array}$ & $\begin{array}{l}\text { Mobility, Furcation } \\
\text { 3.5- or more). }\end{array}$ \\
\hline
\end{tabular}

The mouth is divided into sextants, and six places on every tooth are examined. However, the worst result observed is recorded for the sextant. The WHO periodontal probe was utilized for periodontal estimation [28]. Incompletely erupted teeth and retained roots were excluded.

\section{Statistical Analysis}

Data were analysed using SPSS version 24 , and statistical descriptions were performed by frequency and percent. The chi-square test was used to assess the association of BMI-forage and gender with periodontal health (codes $0,1,2$, and 3). Additionally, two-way ANOVA was performed to identify the effect of BMI-forage, gender and both on periodontal health.

\section{RESULTS}

Descriptive statistics in Table II show the frequency and percentage of each code and allocation of the sample to different study groups for both genders (male and female) and for all weight classes (healthy, overweight, and obese). The frequency of code 0 was higher in the male group (112) than in the female group (13). Code 1 in the male group was 259 and was 272 in the female group. For code 2, frequencies in the male group and female group were 142 and 206, respectively. In addition, for code 3, the frequency of the male group was 28 , and that of the female group was 48. None of the study subjects showed any manifestations for code 4 , so code 4 was omitted from the results. The frequency and percentage of each code and allocation of the sample to different study groups, depending on the BMI-for-Age (healthy, overweight, and obese), were for code 0 (healthy 40, overweight 49, and obese 36). Code 1 was healthy (150), overweight (199), and obese (182). For code 2, frequencies were (healthy 140, overweight 103, and obese 105). In addition, for code 3 , frequencies were healthy 28 , overweight 9 , and obese 39 .

Additionally, the chi-square test in Table II revealed a highly significant association between BMI-for-age and periodontal health (codes 0,1 , 2 and 3 ) at a $p$-value $=0.000$. The association between gender and periodontal health was highly significant in code 3 ( $p$-value $=0.000)$, significant in codes 0 and 1 ( $p$-value $=0.032$ and 0.031 , respectively), and insignificant in code 2 ( $p$-value $=0.520)$. 
Table II - Descriptive Statistics (Frequency and Percentage of Each Code for Both Genders) \& Association of Periodontal Health Status with Gender \& BMl-for-Age

\begin{tabular}{|c|c|c|c|c|c|c|c|c|c|}
\hline Variables & & $\begin{array}{c}\text { Code } 0 \\
\text { Frequency (\%) }\end{array}$ & p-value & $\begin{array}{c}\text { Code1 } \\
\text { Frequency } \\
\text { (\%) }\end{array}$ & $p$-value & $\begin{array}{c}\text { Code } 2 \\
\text { Frequency } \\
(\%)\end{array}$ & $p$-value & $\begin{array}{c}\text { Code } 3 \\
\text { Frequency } \\
(\%)\end{array}$ & $p$-value \\
\hline \multirow{2}{*}{ Gender } & Male & $112(89.6)$ & \multirow{2}{*}{$0.032^{*}$} & $259(48.8)$ & \multirow{2}{*}{$0.031^{\star}$} & $142(40.8)$ & \multirow{2}{*}{0.520} & $28(36.8)$ & \multirow{2}{*}{$0.000^{\star \star}$} \\
\hline & Female & $13(10.4)$ & & $272(51.2)$ & & 206 (59.2) & & $48(63.2)$ & \\
\hline \multirow{3}{*}{$\begin{array}{l}\text { BMI-For- } \\
\text {-Age }\end{array}$} & Healthy & $40(32)$ & \multirow{3}{*}{$0.000^{\star \star}$} & $150(28.2)$ & \multirow{3}{*}{$0.000^{\star \star}$} & $140(40.2)$ & \multirow{3}{*}{$0.000^{\star \star}$} & $28(36.8)$ & \multirow{3}{*}{$0.000^{\star \star}$} \\
\hline & Overweight & $49(39.2)$ & & $199(37.5)$ & & $103(29.6)$ & & $9(11.8)$ & \\
\hline & Obese & $36(28.8)$ & & $182(34.3)$ & & $105(30.2)$ & & $39(51.3)$ & \\
\hline
\end{tabular}

p-value of chi-square test, ${ }^{*}$ Significant at $P$-value $\leq 0.05$, ${ }^{*}$ Highly significant at $\mathrm{P}$ value $<0.001$, BMl for Age: Body Mass Index for Age, \%: Percentage

In subsequent statistical analysis, Table III, two-way ANOVA for the study group showed that the effect of gender on periodontal health status was highly significant at p-value (0.000), and the effect of BMI-for-age on periodontal health status was significant at p-value (0.043). In contrast, the effect of the interaction between gender and BMI-for-age on periodontal health status was insignificant ( $\mathrm{p}$-value $=0.235$ ).

Table III - The effect of gender and BMI-for-age on periodontal health status

\begin{tabular}{|ccc|}
\hline Variables & \multicolumn{2}{c|}{$\begin{array}{c}\text { Periodontal Health Status } \\
\text { (PSR Index Mean) }\end{array}$} \\
\hline Gender & $\boldsymbol{f}$ & $\boldsymbol{p}$ \\
\hline BMI-for-age & 15.223 & $0.000^{\star *}$ \\
\hline Gender*BMI-for-age & 3.207 & $0.043^{\star}$ \\
\hline
\end{tabular}

$f$ : $f$ value of two-way ANOVA, *Significant at P-value $\leq 0.05$, ${ }^{* *}$ Highly significant at $P$ value $<0.001$

\section{DISCUSSION}

Periodontal diseases are multifactorial infective and inflammatory diseases characterized by the existence of supraand subgingival plaque, which provoke an inflammatory host reaction $[9,29]$.

As previously described by many reports, among children and adolescents, gingivitis is the most predominant illness. The rapport of obesity with oral hygiene in adolescents has been inconclusive until now. While in adults, there is a pure connotation between these two factors [30].

Our results indicate a significantassociation between BMI-for-age and periodontal health status, which is represented by codes $0,1,2$, and 3. Similar findings for the effect of obesity on periodontal health in adolescents have been reported by "Modeer et al. 2011 and IrigoyenCamacho et al. 2014" [31,32].

The overall outcomes indicate a confirmed effect and association of overweight and obesity on the incidence of periodontal disease. This effect could be due to an altered reaction to microbial defy, as obesity is known to induce exaggerated inflammatory conditions or affect periodontal disease status [33]; consequently, obesity might have detrimental effects on host reactions by modifying $\mathrm{T}$-cell and macrophage function [34].

Obesity is accompanied by secretion of pro-inflammatory cytokine, adipokines, and other bioactive materials that might lead to amplified inflammation of the gingiva and/ or destruction of the periodontium related to periodontal disease $[32,35,36]$.

The adolescent periodontal condition can be potentially affected by increased adiposity throughout childhood via various mechanisms. Otherwise, adiposity serves as an indicator of a harmful lifestyle that result in periodontal 
disease [18,37]. Additionally, obesity initiates an immune response by producing chronic inflammatory conditions $[17,38]$.

The complicated system of cytokines and further mediators implicated in obesity might be nourished by chronic inflammation of periodontal disease. The formerly disturbed inflammatory cytokine network in the gingival crevice causes advanced damage in the periodontium, which is aggravated by specific inflammatory markers liberated from fatty tissue. Adipose tissue is a dynamic endocrine structure that discharges plentiful cytokines and adipokines [39,40].

The affirmative interconnection concerning obesity and gingival bleeding as formerly present among young adults is possibly clarified by all of these potential mechanisms $[37,41]$. Gingival bleeding is a pathological marker of periodontal diseases [42]. This interconnection indicates that these overweight and obese teenagers could be increased risk for chronic systemic inflammation. Even in an early lifetime, inflammatory reaction disturbances can affect periodontal tissues [37].

Hence, the hypothesis proposed that the combined effect of metabolic and inflammatory outlines along with ignored behaviour concerning oral health in addition to over-all health personnel carefulness might have a vital part in the link of weight state with periodontal condition $[43,44]$.

In this study, we found a significant association of gender with periodontal health status (codes 0,1 , and 3 ) and a highly significant effect of gender on periodontal condition. Some studies, "AlJehani, 2014; Genco and Borgnakke, 2013" [45,46], have shown that males are greater risk for periodontitis than females, while others, "Laine, 2002" [47], propose that females may sometimes be more susceptible to the advancement of periodontitis as a result of hormonal variations that augment gingival inflammation.
Although the effect of gender on periodontal health status was highly significant and the effect of BMI-for-age on periodontal health status was significant, the effect of the interaction between gender and BMIfor-age on periodontal health status was insignificant. Therefore, future cross-sectional and longitudinal studies with a larger number of participants will be essential to understand the nature, magnitude, and mechanism by which obesity affects periodontal disease in adolescents.

Additionally, the consequence of commonly ignored behaviours concerning oral illness avoidance, including personnel sanitation techniques, nutritional information, and routine oral prevention visits, should be kept in mind [43].

Since periodontal disease and obesity are preventable pandemics, proper information and education about their adverse effects should be systemically introduced as part of general health classes given to students of this age to encourage them to adopt healthy lifestyles.

In this study, students with periodontal health problems (codes 1, 2 \& 3) were informed of the importance of oral hygiene measures, the proper technique for brushing, and the need for surface debridement (codes $2 \& 3$ ). Additionally, overweight/obese adolescents were advised to visit a nutritional specialist for information on a proper and healthy diet.

\section{CONCLUSIONS}

The outcomes of this study emphasize the negative influence of obesity on gingival tissue health in young individuals and the need to regularly evaluate BMI-for-age to intercept the negative effect of obesity/overweight on oral and general health.

Additionally, on a clinical level, the relationship between paediatricians and dentists 
should be encouraged to achieve the best outcome for adolescent health.

\section{REFERENCES}

1. World Health Organization. Obesity: preventing and managing the global epidemic. report of a WHO Consultation on obesity \& World Health Organization (WHO Technical Report Series 894). Geneva: Report;2000.

2. Kopelman PG. Obesity as a medical problem. Nature. 2000; 404(6778):63543. doi: $10.1038 / 35007508$

3. Fadel HT, Pliaki A, GronowitzE, Marild S, Ramberg P,Dahlen, et al. Clinical and biological indicators of dental caries and periodontal disease in adolescents with or without obesity. Clin Oral Investig. 2014; 18(2):359-68. doi: 10.1007/ s00784-013-0972-9.

4. Wang Y,Lobstein T. Worldwide trends in childhood overweight and obesity. Int J Pediatr Obes. 2006; 1(1):11-25. doi:10.1080/17477160600586747

5. Han JC, Lawlor DA, Kimm SY. Childhood obesity. Lancet. 2010; 375(9727):1737-48. doi: 10.1016/S0140-6736(10)60171-7.

6. World Health Organization. Countrywide Integrated Non-communicable Diseases Intervention (CINDI) Programme. Report 1995.

7. Petersen PE, Bourgeois D, Ogawa H, Estupinan-Day S, Ndiaye C. The global burden of oral diseases and risks to oral health. Bull World Health Organ. 2005; 83(9)661-9.

8. López R, Fernández 0, Baelum V. Social gradients in periodontal diseases among adolescents. Community Dent Oral Epidemiol. 2006 Jun;34(3):18496. doi: 10.1111/.j.1600-0528.2006.00271.x

9. Oppermann RV, Weidlich P,Musskopf ML. Periodontal disease and systemic complications. Braz Oral Res. 2012;26 Suppl 1:39-47. doi: 10.1590/s180683242012000700007.

10. Bimstein E, Huja PE, Ebersole JL. The potential lifespan impact of gingivitis and periodontitis in children. J Clin Pediatr Dent. 2013 Winter;38(2):95-9. doi: 10.17796/jcpd.38.2.j525742137780336.

11. Chrysanthakopoulos NA. Prevalence of gingivitis and associated factors in 13-16-year-old adolescents in Greece.Eur J Gen Dent 2016;5(2):58-64. doi: 10.4103/2278-9626.179536

12. Eke PI, Dye BA, Wei L, Slade GD, Thornton-Evans G0, Borgnakke WS, et al. Update on prevalence of periodontitis in adults in the United States: NHANES 2009 to 2012. J Periodontol. 2015 May;86(5):611-22. doi:10.1902/ jop.2015.140520.

13. Slade GD, Spencer AJ, Roberts-Thomson KF. Australia's dental generations. Natl Surv Adult Oral Health 2004;6 274.

14. Al-Zahrani MS, Bissada NF, BorawskitEA. Obesity and periodontal disease in young, middle-aged, and older adults. J Periodontol. 2003 May;74(5):610-5. doi:10.1902/jop.2003.74.5.610

15. Larson NI, Story M. The pandemic of obesity among children and adolescents: what actions are needed to reverse current trends? J Adolesc Health. 2007 Dec;41(6):521-2. doi: 10.1016/j.jadohealth.2007.09.008

16. Alabdulkarim M, Bissada N, Al-Zahrani M, Ficara A, Siegel B. Alveolar bone loss in obese subjects. J Int Acad Periodontol. 2005; 7(2):34-8.

17. Genco RJ, Grossi SG, Ho A, Nishimura F, Murayama Y. A Proposed model linking inflammation to obesity, diabetes, and periodontal infections. J Periodontol. 2005 Nov;76 Suppl 11S:2075-2084. doi: 10.1902/ jop.2005.76.11-S.2075
18. Ekuni D, Yamamoto T, Koyama R, Tsuneishi M, Naito K, Tobe K. Relationship between body mass index and periodontitis in young Japanese adults. J Periodontal Res. 2008 Aug;43(4):417-21. doi: 10.1111/j.1600-0765.2007.01063.x.

19. Khan S, Barrington G, Bettiol S, Barnett T, Crocombe L. Is Overweight/ Obesity a Risk Factor for Periodontitis in Young Adults and Adolescents? A Systematic Review. Obes Rev. 2018; 19(6):852-883.. doi: 10.1111/obr.12668.

20. Martens L, De Smet S, Yusof MY, Rajasekharan S. Association between overweight/obesity and periodontal disease in children and adolescents: a systematic review and meta-analysis. Eur Arch Paediatr Dent. 2017 Apr;18(2):69-82. doi: 10.1007/s40368-017-0272-1

21. Range H, Poitou C, Boillot A, Ciangura C, Katsahian S, Lacorte J, et al. Orosomucoid, A new biomarker in the association between obesity and periodontitis. PLoS One. 2013; 8(3):e57645. doi: 10.1371/journal.pone.0057645

22. Lewis CW, Johnston BD, Linsenmeyar KA, Williams A, Mouradian W. Preventive dental care for children in the United States: a national perspective. Pediatrics. 2007 Mar;119(3):e544-53. doi: 10.1542/peds.20061958

23. Hujoel PP, Drangsholt M, Spiekerman C, DeRouen TA. Periodontitis-systemic disease associations in the presence of smoking-causal or coincidental? Periodontol 2000. 2002; 30:51-60. doi: 10.1034/j.1600-0757.2002.03005.x.

24. World Health Organization.WHO [Internet]. BMl-for-age (5-19 years). Available via WH0; 2007. Available from:http://www.who.int/growthref/ who2007_bmi_for_age/en/index.html.

25. Macek MD, Mitola DJ. Exploring the association between overweight and dental caries among US children. Pediatr Dent. 2006; 28(4):375-80.

26. World Health Organization. Physical status: the use and interpretation of anthropometry: Report of a WHO Expert Committee. WHO Technical Report Series 854. Geneva:WH0; 1995.

27. Jeffcoat MK, McGuire M, Newman MG. Evidence-based periodontal treatment. Highlights from the 1996 World Workshop in Periodontics. J Am Dent Assoc. 1997 Jun;128(6):713-24. doi: 10.14219/jada.archive.1997.0294

28. Garnick JJ, Silverstein L. Periodontal probing: probe tip diameter. J Periodontol. 2000 Jan;71(1):96-103. doi: 10.1902/jop.2000.71.1.96.

29. Suresh S, Mahendra J. Multifactorial relationship of obesity and periodontal disease. J Clin Diagn Res. 2014 Apr;8(4):ZE01-3. doi: 10.7860/ JCDR/2014/7071.4227

30. Nascimento GG, Seerig LM, Vargas-Ferreira F, Correa F0, Leite FR, Demarco FF. Are obesity and overweight associated with gingivitis occurrence in Brazilian schoolchildren? J Clin Periodontol. 2013 Dec;40(12):1072-8. doi: 10.1111/jcpe.12163

31. Modéer T, Blomberg C, Wondimu B, Lindberg TY,Marcus C. Association between obesity and periodontal risk indicators in adolescents. Int J Pediatr Obes. 2011 Jun;6(2-2):e264-70. doi: 10.3109/17477166.2010.495779

32. Irigoyen-Camacho ME, Sanchez-Perez L, Molina-Frechero N, VelazquezAlva C,Zepeda-Zepeda M, Borges-Yanez A. The relationship between body mass index and body fat percentage and periodontal status in Mexican adolescents. Acta Odontol Scand. 2014 Jan;72(1):48-57. doi: 10.3109/00016357.2013.797100.

33. Dixon JB, O'Brien P. A disparity between conventional lipid and insulin resistance markers at body mass index levels greater than $34 \mathrm{~kg} / \mathrm{m}(2)$. Int J Obes Relat Metab Disord. 2001 Jun;25(6):793-7. doi: 10.1038/sj.j.jo.0801624

34. Lamas 0, Marti A, Martínez JA. Obesity and immunocompetence. Eur J Clin Nutr.2002 Aug;56 Suppl 3:S42-5. doi:10.1038/s.ejcn.1601484 
35. Kawanami D, Maemura K, Takeda N, Harada T, Nojiri T, Imai Y, et al. Direct reciprocal effects of resistin and adiponectin on vascular endothelial cells: a new insight into adipocytokine endothelial cell interactions. Biochem Biophys Res Commun. 2004;314(2):415-9. doi:10.1016/j.bbrc.2003.12.104

36. Scorzetti L, Marcattili D, Pasini M, Mattei A, Marchetti E, Marzo G. Association between obesity and periodontal disease in children. Eur J Paediatr Dent. 2013; 14(3):181-4.

37. Reeves AF, Rees JM, Schiff M, Hujoel P. Total body weight and waist circumference associated with chronic periodontitis among adolescents in the United States. Arch Pediatr Adolesc Med. 2006 Sep;160(9):894-9. doi: 10.1001/archpedi.160.9.894.

38. Das UN. Is obesity an inflammatory condition? Nutrition. 2001;17(11-12):95366.

39. Ahima RS, Flier JS. Adipose tissue as an endocrine organ. Trends Endocrinol Metab. 2000; 11(8):327-32. doi:10.1016/s1043-2760(00)00301-5

40. Greenburg AS, Obin MS. Obesity and the role of adipose tissue in inflammation and metabolism. Am J Clin Nutr. 2006; 83(2):461S-465S. doi: 10.1093/ajcn/83.2.461S
41. Sarlati F, Akhondi N, Ettehad T, Neyestani T,Kamali Z. Relationship between obesity and periodontal status in a sample of young Iranian adults. Int Dent J. 2008; 58(1):36-40.

42. Kinane FD, Hodge PJ. Periodontal disease in children and adolescents: introduction and classification. Periodontol 2000. 2001;26:7-15.

43. Franchini R, Petri A, Migliario M, Rimondini L. Poor oral hygiene and gingivitis are associated with obesity and overweight status in pediatric subjects. J Clin Periodontol. 2011; 38(11):1021-8. doi: 10.1111/j.1600-051X.2011.01770.x

44. Thomson WM, Sheiham A, Spencer AJ. Sociobehavioral aspects of periodontal disease. Periodontol 2000.;60(1):54-63. doi:10.1111/.16000757.2011.00405.X.

45. AlJehani YA. Risk factors of periodontal disease: review of the literature. Int $J$ Dent. 2014; 2014:182513. doi:10.1155/2014/182513

46. Genco RJ, Borgnakke WS. Risk factors for periodontal disease. Periodontol 2000.2013;62(1):59-94. doi:10.1111/j.1600-0757.2012.00457.x.

47. Laine MA. Effect of pregnancy on periodontal and dental health. Acta Odontol Scand. 2002; 60(5):257-64. doi: 10.1080/00016350260248210

\section{Athraa Ali Mahmood}

\section{(Corresponding address)}

Periodontal Department, Dentistry College, Mustansiri-

yah University, Baghdad, Iraq.

Date submitted: 2020 Mar 18

Email: athrauali@gmail.com 